\title{
Tibial osteomyelitis with cold abscess within calf muscles in a toddler referred with suspected oligoarthritis to rheumatology clinic
}

\author{
Dhanarathnamoorthy Vetrichelvan, ${ }^{1}$ Umapathy Pasupathy, ${ }^{1}$ Elayaraja Sivaprakasam, ${ }^{1}$ \\ Mahesh Janarthanan²
}

'Department of Paediatrics, Sri Ramachandra University, Chennai, India

${ }^{2}$ Division of Pediatric Rheumatology, Dept of Pediatrics, Sri Ramachandra University, Chennai, Tamilnadu, India

\section{Correspondence to} Dr Mahesh Janarthanan, maheshjanarthanan@hotmail. com

Accepted 29 August 2018
Check for updates

(c) BMJ Publishing Group Limited 2018. No commercial re-use. See rights and permissions. Published by BMJ.

\begin{tabular}{|l|}
\hline To cite: Vetrichelvan D, \\
Pasupathy U, Sivaprakasam E, \\
et al. BMJ Case Rep \\
Published Online First: \\
[please include Day Month \\
Year]. doi:10.1136/bcr-2018- \\
227092
\end{tabular}

\section{DESCRIPTION}

A 2-year-old male child was referred to the paediatric rheumatology clinic with history of limping, swelling of right knee and low-grade fevers for 6 weeks. About 2 months prior to this presentation, he had an episode of upper respiratory infection which was followed by swelling of the right knee. He was initially treated with oral analgesics by his primary physician. After 6 weeks when there was no improvement, he was referred for evaluation of possible juvenile idiopathic arthritis.

On examination, there was visible swelling of his right knee compared with his left and he was refusing to bear weight on his right lower limb (figure 1). On closer observation, a diffuse swelling was noted over the right calf region with fullness of the popliteal fossa (figure 1). The swelling was not warm or tender. There was no contact history with tuberculosis. The patient had no lymphadenopathy or hepatosplenomegaly and had a normal chest examination. A BCG scar was present. Routine investigations were normal except for a high erythrocyte sedimentation rate (ESR) of 72. Chest X-ray and X-ray of right knee were normal and Mantoux test was negative.

An ultrasound scan revealed an abscess within the calf muscles (figure 2). An MRI also revealed marrow oedema in tibial diaphysis with periosteal reaction and extension of abscess into the intermuscular plane (figure 3). Incision and drainage of the cold abscess was performed and Mycobacterium tuberculosis was detected by staining for acidfast bacilli and by genexpert method. A diagnosis of tubercular osteomyelitis of the tibia with cold abscess was confirmed. The patient was commenced on four-drug antitubercular therapy with rifampicin, isoniazid, ethambutol and pyrazinamide for 2 months followed by rifampicin, isoniazid and ethambutol for 8 months.

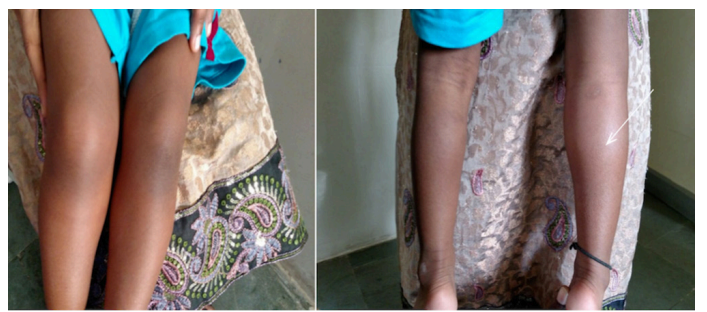

Figure 1 Diffuse swelling of right knee and calf region.

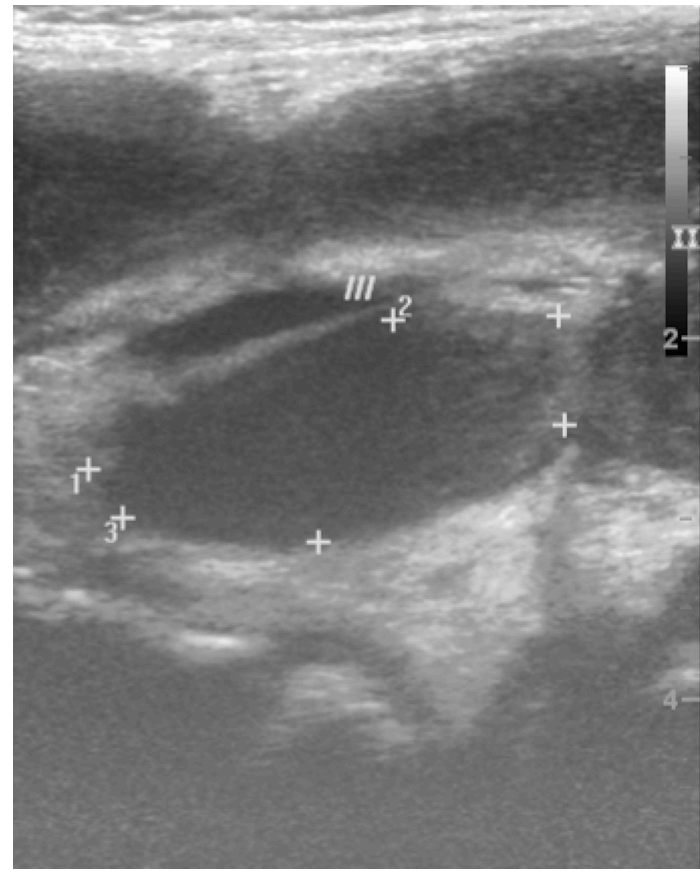

Figure 2 Ultrasound showing abscess within the calf muscles.

A sinus tract formed at the site of incision and drainage and healed over a course of few weeks. The patient completed the course of antitubercular therapy and is well on follow-up with no bony deformity or limb length discrepancy.

Skeletal tuberculosis (TB) in children accounts for about $1 \%-2 \%$ of all TB cases. In order of frequency, the commonly affected bones include the spine, femur, tibia and fibula. ${ }^{1}$ Skeletal TB occurs by haematogenous or lymphatic spread from mostly a primary pulmonary site. ${ }^{2}$ Cases of skeletal TB without primary site involvement have also been described. TB osteomyelitis usually presents with swelling only or swelling and pain of the affected bone. Systemic manifestations such as fever may be low grade in nature. Diagnosis may be delayed by several months and X-rays taken early in the course of the disease may be normal. Elevation of non-specific inflammatory markers such as $\mathrm{C}$ reactive protein and ESR may be the only finding. The gold standard for diagnosis continues to be demonstrating the presence of TB bacilli in bone biopsy, cultures or staining. Treatment usually 


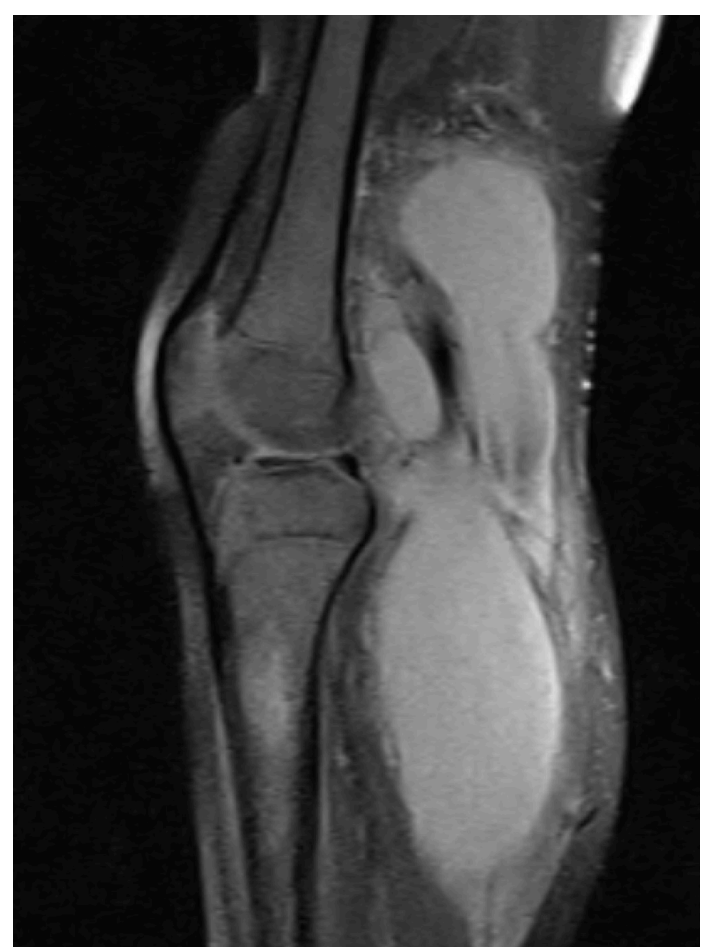

Figure $3 \mathrm{MRI}$ showing marrow oedema in tibial diaphysis with periosteal reaction.

consists of a combination of surgical debridement and antitubercular therapy.

\section{Learning points}

- Tuberculosis should be considered as differential diagnosis in children presenting with monarthritis.

- X-rays of joints and bones may be normal in osteomyelitis in early stages of the disease.

TB cold abscess is usually associated with osteomyelitis of an adjacent bone, but primary cold abscess without bone involvement has also been reported in children. Though cases of tibial osteomyelitis have been reported in the past, to our knowledge this is the only case of tibial osteomyelitis with cold abscess within calf muscles. ${ }^{3}$

Contributors MJ contributed to the conception, design, drafting, critical revision and final approval of the article. DV contributed to the design, drafting and final approval of article. UP and ES contributed to drafting, literature search and final approval. The final proof was approved by all authors.

Funding The authors have not declared a specific grant for this research from any funding agency in the public, commercial or not-for-profit sectors.

Competing interests None declared.

Patient consent Parental/guardian consent obtained

Provenance and peer review Not commissioned; externally peer reviewed.

\section{REFERENCES}

1 Vallejo JG, Ong LT, Starke JR. Tuberculous osteomyelitis of the long bones in children. Pediatr Infect Dis J 1995:14:542-6.

2 Teo HE, Peh WC. Skeletal tuberculosis in children. Pediatr Radiol 2004;34:853-60.

3 Hiddema WB, Barnard BW, Bouaicha W, et al. Infantile tuberculous osteomyelitis of the proximal tibia involving the growth plate. SA Orthop J 2012;11:84-7.

Copyright 2018 BMJ Publishing Group. All rights reserved. For permission to reuse any of this content visit

http://group.bmj.com/group/rights-licensing/permissions.

BMJ Case Report Fellows may re-use this article for personal use and teaching without any further permission.

Become a Fellow of BMJ Case Reports today and you can:

- Submit as many cases as you like

- Enjoy fast sympathetic peer review and rapid publication of accepted articles

Access all the published articles

- Re-use any of the published material for personal use and teaching without further permission

For information on Institutional Fellowships contact consortiasales@bmjgroup.com

Visit casereports.bmj.com for more articles like this and to become a Fellow 